\title{
Innate talent is adaptable - comment on Baker \& Wattie
}

\author{
Michael Romann ${ }^{1, *}$ \\ 1 Swiss Federal Institute of Sport Magglingen (SFISM), Magglingen, Switzerland \\ * Corresponding author: Swiss Federal Institute of Sport Magglingen, Alpenstrasse 18, CH-2532 Magglingen, Switzerland \\ E-Mail:michael.romann@baspo.admin.ch
}

\section{COMMENTARY}

\section{Article History:}

Submitted $10^{\text {th }}$ December 2018

Accepted $21^{\text {th }}$ December 2018

Published $7^{\text {th }}$ May 2019

Handling Editor:

Lisa Steidl-Müller

University of Innsbruck, Austria

Editor-in-Chief:

Martin Kopp

University of Innsbruck, Austria

\section{ABSTRACT}

A recent article by Baker and Wattie (2018) provided an update on the widely cited review of "Innate Talent" by Howe, Davidson and Sloboda (1998). The article summarizes that the defined criteria for "Innate Talent" are still valid, standing the test of time. However, new findings in epigenetics should be considered. The epigenome interacts with environmental factors, such as physical exercise, contributing to phenotypical and performance differences of the same gene. In this context, researchers in sport science face the task of defining ethical standards that are accepted by society. From an epigenetic perspective, one should refrain from thinking that genetics have a fixed performance outcome, since the epigenome is adaptable. Instead, research and practice should consider how created environments support athlete development.

Keywords:

Aptitude - Sports - Giftedness

Citation:

Romann, M. (2019): Innate talent is adaptable - comment on Baker \& Wattie Current Issues in Sport Science, 4:105. doi: 10.15205/CISS_2019.105 This is a commentary on a CISS report article authored by Baker, J. \& Wattie, N. (2018). Innate talent in sport: Separating myth from reality. Current Issues in Sport Science, 3:006. doi: 10.15203/CISS_2018.006

\section{Introduction}

As a researcher in youth sport, I appreciate the article by Baker \& Wattie (2018), as it emphasizes the importance of talent development and the developmental process. It also provides a convincing overview of the history of research alongside recent findings on the topic of "Innate Talent". The extent to which physical performance of an individual is predetermined by genes has been a heavily discussed topic in (sport) science. Given the knowledge of genetic factors influencing physical performance, it has been suggested that genome analyses could potentially identify elite athletes from an early age (Rupert, 2003). It has also been suggested that such an approach could improve the time-consuming and expensive scouting procedures conducted for new athletic potential (Sharp, 2008). As a direct result of the decoding of the human genome in 2001 (Venter et al., 2001), the search for specific genes that influence and predict elite athletic performance has received a lot of attention. With the advancement of technology, the once simple idea of "one-gene-encodes-one-phenotype" was adapted several times and finally extended to the "one-geneone-polypeptide" definition (Gerstein et al., 2007). In future, the research on epigenetics in sport might have a significant impact on the design of talent development programs and ultimately, the performance of individual athletes. This comment therefore focuses on the concept of talent in sport, the rarely discussed key area of epigenetics, and the ethical implications of genetic testing and practical implications for sport science.

\section{Concept of talent in sport}

In the area of sporting talent development, recognized researchers present talent as a set of personal characteristics that enhance one's ability to achieve expertise at an accelerated rate in a specific sport (Vaeyens, Lenoir, Williams, \& Philippaerts, 2008). Likewise, they recognise that talent exists when certain individual prerequisites are combined with an effortful development process. Often, elite athletic performance is described as being the result of biological or genetically constrained fac- 
tors (i.e. nature) and the end-product of experience and learning (i.e. nurture) (Coutinho, Mesquita, Fonseca, \& De MartinSilva, 2014). On this basis, the aim of talent identification is to assess a person's potential for future performance (Rees et al., 2016; Vaeyens, Lenoir, Williams, \& Philippaerts, 2008). However, identifying and predicting performance potential at a young age is a difficult and complex process, as development is non-linear, unstable and multifactorial (Cobley \& Till, 2017). To further complicate matters, there are multiple interactions between prerequisites, which may change over time (SchmittNey, Happ, Ball, \& Groner, 1992; Cobley \& Till, 2017). While an individual's genome could be described as being relatively static, the epigenome can be dynamic, altered by environmental conditions and stimuli (to a degree). Epigenetics therefore provides the bridge between nature and nurture in the concept of talent.

\section{Epigenetics}

Epigenetics is the term used to describe inheritable changes in gene expression that are not based on changes in the DNA sequence. In other words, a change in the phenotype while the genotype remains the same. Epigenetic changes are a regular, natural and reversible event (Egger, Liang, Aparicio, \& Jones, 2004). The epigenome consists of nuclear information that is hereditary during cell division and controls development, tissue differentiation and cellular responsiveness. Epigenetic information is controlled by the genome sequence, environment, stochastics and chance. As such, epigenetics is at the interface between genome, development and environmental exposure (Feinberg, 2018). There is growing evidence that athletic performance is influenced not only by the mere genetic code, but also by numerous processes that influence gene expression transcriptionally and post-transcriptionally and that some form of gene-for-environment interaction exists (Ehlert, Simon, \& Moser, 2013). Epigenetic effects can therefore play a significant role in the expression and determination of athletic potential (Rees et al., 2016). At the genetic and epigenetic level, there is evidence that gene variants explain a significant amount of variance in a variety of expressions such as endurance and muscle strength, which in turn are influenced by physiological processes, such as physical exercise (Haugaasen, Toering, \& Jordet, 2014; Rees et al., 2016). Fraga \& colleagues (2005) provided evidence that the gene expression of monozygotic twins differ with increasing age and the more their lifestyles vary. In summary, environmental factors, such as physical exercise, interact with the epigenome contributing to phenotypical and performance differences of the same genome. Whether the sports science community should employ forms of genetic testing on this basis, raised multiple questions, including ethical questions for sports medicine in talent development.

\section{Ethical implications of genetic testing}

According to the Council of Europe Bioethics Convention and the US Genetic Information Non-discrimination Act, tests on gene predisposition are ethically, or legally, applicable only for strict health reasons and not for capacity evaluation or employment purposes [20]. Given the economic rewards and the prestige of professional sports, the use of genetic testing under the veil of health reasons and privacy protection might be underestimated. As a result, ethical standards should strictly prohibit the use of invasive genetic manipulation to improve performance in sport (McNamee, Müller, van Hilvoorde, \& Holm, 2009; WADA, 2018). On the other hand, interventions that are external and not invasive might be acceptable. This could include the creation of an environment that supports health, exercise selection, training programs, nutrition and regeneration for a performance-enhancing gene expression (Guilherme, Tritto, North, Lancha-Júnior, Artioli, 2014).

\section{Practical implications}

Since the environment also determines how the genotype is converted into the phenotype, genetics should be considered in the process of talent development in a dynamic, multiplicative and multidimensional manner (Simonton, 1999). In order control the environmental influences longitudinally, a panel study design should be chosen wherever possible. Based on existing evidence, the mindset that talent is innate, fixed and immutable can be refuted. In addition, the effort to recognize talents as early as possible (before puberty) and to commit to this decision is problematic. This "fixed-mindset" of epigenetics might hinder optimal talent development. According to the self-theory by Dweck (2013) individuals who believe in their talent, or even that their gene expression can be developed through hard work and input from others have a "growth mindset". They tend to achieve more than those with a more "fixed mindset" (those who believe their talents are innate). There is evidence that gene expression is not fixed, but adaptable and that gene expression can be positively influenced by a constant effort to improve. This is not only important for researchers, but also for coaches. Both of whom should adapt to such knowledge to optimize the athlete's environment.

\section{Conclusion}

Research in the epigenetics has provided evidence that talent consistsof interactions between genes and the environment. Therefore epigenetics builds the bridge between the former nature versus nurture debate. In the future, epigenetic characteristics and their potential influence on athletic performance should be considered, researched and validated with the help of well-controlled model systems to transfer them into the training environment. In doing so, the sport science commu- 
nity will face the difficult task of defining ethical standards that prohibit gene manipulation, but will allow the creation of an environment that produce performance-enhancing gene expression. This requires researchers from the fields of genetics, epigenetics, sports science and stakeholders of sport federations to work together in a multidisciplinary way.

\section{Acknowledgements}

I would like to express my gratitude for the revision and helpful comments by Marie Javet, Jörg Fuchslocher, Dennis-Peter Born and Stephen Cobley.

\section{Funding}

The authors have no funding or support to report.

\section{Competing Interests}

The authors have declared that no competing interests exist.

\section{Data Availability Statement}

All relevant data are within the paper.

\section{References}

Cobley, S., Till, K. (2017). Longitudinal studies of athlete development: Their importance, methods and future considerations. In Joseph Baker, Stephen Cobley, Jorg Schorer, Nick Wattie (Eds.), Routledge Handbook of Talent Identification and Development in Sport, (pp. 250-268). Abingdon: Routledge.

Coutinho, P., Mesquita, I., Fonseca, A. M., \& De Martin-Silva, L. (2014). Patterns of sport participation in Portuguese volleyball players according to expertise level and gender. International Journal of Sports Science \& Coaching, 9(4), 579-592.

Dweck, C. S. (2013). Self-theories: Their role in motivation, personality, and development: Psychology press.

Egger, G., Liang, G., Aparicio, A., \& Jones, P. A. (2004). Epigenetics in human disease and prospects for epigenetic therapy. Nature, 429(6990), 457.

Ehlert, T., Simon, P., \& Moser, D. A. (2013). Epigenetics in sports. Sports Medicine, 43(2), 93-110.

Feinberg, A. P. (2018). The key role of epigenetics in human disease prevention and mitigation. New England Journal of Medicine, 378(14), 1323-1334.

Fraga, M. F., Ballestar, E., Paz, M. F., Ropero, S., Setien, F., Ballestar, M. L., ... Benitez, J. (2005). Epigenetic differences arise during the lifetime of monozygotic twins. Proceedings of the
National Academy of Sciences, 102(30), 10604-10609.

Gerstein, M. B., Bruce, C., Rozowsky, J. S., Zheng, D., Du, J., Korbel, J. O., ... Snyder, M. (2007). What is a gene, post-ENCODE? History and updated definition. Genome Research, 17(6), 669-681.

Guilherme, JP., Tritto, AC., North, KN., Lancha-Júnior, AH., Artioli, GG. (2014). Genetics and sport performance: current challenges and directions to the future. Rev Bras Educação Fís Esporte; 28(1):177-193.

Haugaasen, M., Toering, T., \& Jordet, G. (2014). From childhood to senior professional football: A multi-level approach to elite youth football players' engagement in football-specific activities. Psychology of sport and exercise, 15(4), 336-344.

Howe, M. J. A., Davidson, J. W. \& Sloboda, J. A. (1998). Innate talents: Reality or myth?

Behavioral and Brain Sciences, 21, 399-422.

McNamee, M. J., Müller, A., van Hilvoorde, I., \& Holm, S. (2009). Genetic testing and sports medicine ethics. Sports Medicine, 39(5), 339-344.

Rees, T., Hardy, L., Güllich, A., Abernethy, B., Côté, J., Woodman, T., ... Warr, C. (2016). The Great British Medalists Project: A Review of Current Knowledge on the Development of the World's Best Sporting Talent. Sports Medicine, 1-18.

Rupert, J. L. (2003). The search for genotypes that underlie human performance phenotypes. Comparative Biochemistry and Physiology Part A: Molecular \& Integrative Physiology, 136(1), 191-203.

Schmitt-Ney, M., Happ, B., Ball, R. K., \& Groner, B. (1992). Developmental and environmental regulation of a mammary gland-specific nuclear factor essential for transcription of the gene encoding beta-casein. Proceedings of the National Academy of Sciences, 89(7), 3130-3134.

Sharp, N. C. (2008). The human genome and sport, including epigenetics and athleticogenomics: a brief look at a rapidly changing field. Journal of Sports Sciences, 26(11), 1127-1133.

Simonton, D. K. (1999). Talent and its development: An emergenic and epigenetic model. Psychological Review, 106(3), 435.

Vaeyens, R., Lenoir, M., Williams, A. M., \& Philippaerts, R. (2008). Talent identification and development programmes in sport: Current models and future directions. Sports Medicine, 38(9), 703-714.

Venter, J. C., Adams, M. D., Myers, E. W., Li, P. W., Mural, R. J., Sutton, G. G., ... Holt, R. A. (2001). The sequence of the human genome. Science, 291(5507), 1304-1351.

World Anti-doping Agency (WADA) Prohibited List (2018). https://www.wada-ama.org/sites/default/files/prohibited_ list_2018_en.pdf. Accessed December 03, 2018. 
